\title{
EFFICIENCY CALIBRATION OF HIGH-PURITY GERMANIUM DETECTOR USING MONTE CARLO SIMULATIONS INCLUDING COINCIDENCE-SUMMING CORRECTIONS: VOLUME SOURCE CASE
}

\author{
M. Konstantinova, D. Germanas, A. Gudelis, and A. Plukis \\ Center for Physical Sciences and Technology, Savanoriu 231, 02300 Vilnius, Lithuania \\ Email: marina.konstantinova@ftmc.lt
}

Received 9 November 2020; revised 15 January 2021; accepted 18 January 2021

\begin{abstract}
The gamma-ray spectrometry by the instrumentality of Ge detectors is used for the detection of low activity environmental samples of different geometry (soil samples, air filters with aerosols, milk powder, etc.). Such measurements require separate calibration of the detector. The high purity germanium ( $\mathrm{HPGe}$ ) gamma-ray spectrometer of GC2520 series was used for experiments. For the efficiency calibration, three cylindrical containers filled with different ${ }^{60} \mathrm{Co}$ water solution levels were used, and the gamma-ray coincidence summing was modelled using MCNP6. The dimensions of the pure germanium crystal, provided by Canberra, were used for the simulations. The true coincidence summing takes place when two or more gamma quanta, which are emitted in a cascade from an excited nucleus, are detected within the resolving time of the detector. However, there is often a mismatch between the simulated and experimental efficiencies. The experimentally obtained and modelled spectra were compared: a good consistency of experimental and modelled results allows investigating the volume sources. During the simulation it was found that the factors affecting the accuracy of modelling are the thickness of the dead layer, crystal dimensions and the thickness of the $\mathrm{Al}$ detector cap. The analysis allows measuring the radionuclides activity concentration of samples placed in the containers with different filling heights having only standard shape calibration sources. The obtained accuracy is sufficient to fulfil criteria of 5-10\% for such type of simulation to be applied for measurements of real samples in standard BURK-60 containers of various sample filling heights.
\end{abstract}

Keywords: HPGe detector, efficiency calibration, MCNP6, coincidence-summing correction

\section{Introduction}

The high purity germanium (HPGe) gamma-ray spectrometry is used for the analysis of environmental samples and the determination of radionuclide concentration due to a sufficiently high resolution. This is one of the most common methods to determine concentrations of gamma-ray emitters in the samples. This non-destructive method does not require a special sample preparation. However, when more precise quantitative results of activity concentration are needed, the efficiency calibration with a varied distance from the source is necessary. For the efficiency calibration, we can use any source with the known radionuclide activity and gamma-ray emission probability [1].
The total efficiency shows how much the detector registers across a wide energy range from a given sample, and how much of other energy released from the sample is from Compton scattering, annihilation peak escapes, etc. Meanwhile, the peak efficiency shows how much the detector registers at a specific energy, hence both peak and total efficiencies should be taken into account to determine the overall efficiency of the detector [2].

The full-energy peak efficiency, frequently referred to as the counting efficiency, may be defined as the ratio of two rates: the peak counting rate and the gamma-ray emission rate of the source,

$$
\varepsilon_{E}=\frac{N_{E}}{A \cdot I_{g}},
$$


where $N_{E}$ is the counting rate due to nuclear transitions in the source, counts per second, $A$ [Bq] is the activity of radionuclide of interest, and $I_{g}$ is the emission probability of the gamma ray with energy $E$. To obtain the results with the lowest possible uncertainty, we have to consider the attenuation of gamma radiation by the sample material itself and apply proper corrections to account for self-absorption when the sample matrix used is of different density and $Z$ number as compared to that which was applied for the calibration. In addition, corrections are needed to the summation effects caused either by large activities of measurable radionuclides or by geometries providing high counting efficiencies usually attainable when using HPGe detectors. Otherwise, the obtained efficiency curve will be degraded towards lower efficiencies leading to overestimation of the activity, especially in the case of radionuclides free of the coincidence-summing effect [3-5].

Monte Carlo simulation is known to be an effective tool to calculate radiation interaction parameters in different types of compounds and mixtures for shielding and energy deposition in human organs and tissues. The applicability of this method is greatly dependent on the accuracy of a geometry model, composition and density distribution of the sample matrix [6-8].

When modelling the gamma radiation of radionuclides with two or more emission peaks, it is necessary to take into account the coincidencesumming effect. The true coincidence summing takes place when two or more gamma rays, which are emitted in a cascade from an excited nucleus, are detected within the resolving time of the detector [9, 10]. However, there is often a mismatch between the simulated and experimental efficiencies. Also, there can be an uncertainty in the parameters, e.g. dead layer thickness, detector end-cap to Ge crystal distance, etc. [11]. In order to improve knowledge of detector dimensions and position, it became common to X-ray or scan it with a collimated beam of photons. The results of those measurements indicate that the error in the detector position as specified by the manufacturer could be a few millimetres, because the manufacturing process is inherently complex, with a significant variability between detectors due to individual processing [12]. Particularly critical, especially in the low energy re- gion, is the dead layer thickness. The dead layer corresponds to the nondepleted detector region, close to the outer surface, that the photon has to pass through before entering the detector's active volume. The depth of this region depends on different (correlated) parameters, linked to the germanium impurity level and to the diode production process. The principal mechanism inducing such a count rate variation would remain the dead layer thickness variation [13.

Thus, the Monte Carlo method helps to avoid problems such as different density and $Z$ of environmental samples, special handling or potential contamination risks, as well as high cost of standards. However, it is necessary to simulate the situation extremely accurately that is difficult because of uncertainty in the detector parameters, and this is especially true of the dead layer. In addition, difficulties arise when you have to take into account the coincidence-summing effect.

The aim of the present work is to design a model which takes into account the coincidencesumming effect and could be used in research of the efficiency calibration of a variety of sources, as well as to estimate which parameters of the detector, and to what degree, most affect the simulation accuracy.

\section{Materials and methods}

\subsection{Measuring}

The gamma-ray spectrometer made by Canberra, USA was used for experiments. The coaxial high purity germanium detector of GC2520 series has a $25 \%$ relative efficiency and a resolution of $2.0 \mathrm{keV}$ at $1.332 \mathrm{MeV}$ and is used for gamma-ray spectrometric analysis in the laboratory. The dimensions of the germanium crystal, provided by Canberra, were used for the simulations (Figs. 1, 2). Three cylindrical containers filled with different levels of ${ }^{60} \mathrm{Co}$ water solution were measured, and the spectra were numerically simulated (Table 1 ). The ${ }^{60} \mathrm{Co}$ water solution was produced in the Ionizing $\mathrm{Ra}$ diation Metrology Laboratory of the Department of Metrology, Center for Physical Sciences and Technology (FTMC) and placed into the standard BURK-60 container (cylinder with diameter of $64 \mathrm{~mm}$ and height of $22 \mathrm{~mm}$ ). Activities were recalculated taking into account the radioactive decay. 
(a)

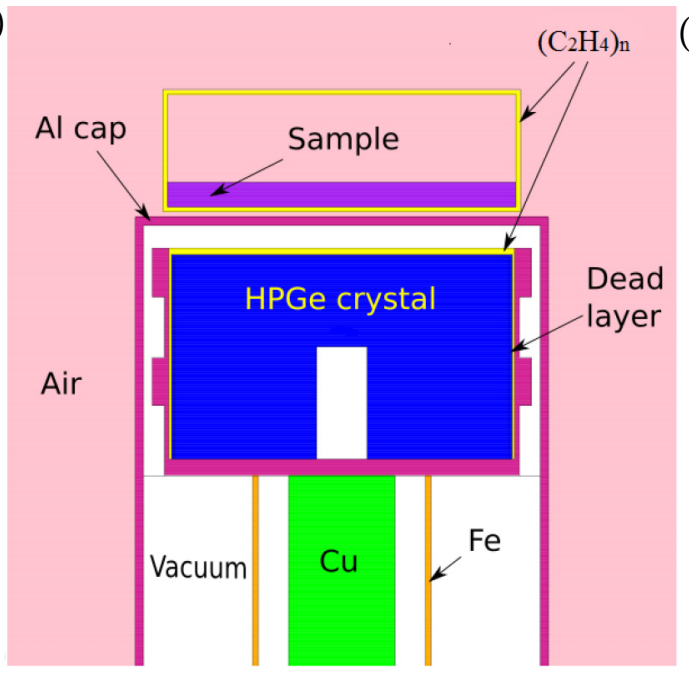

(b)

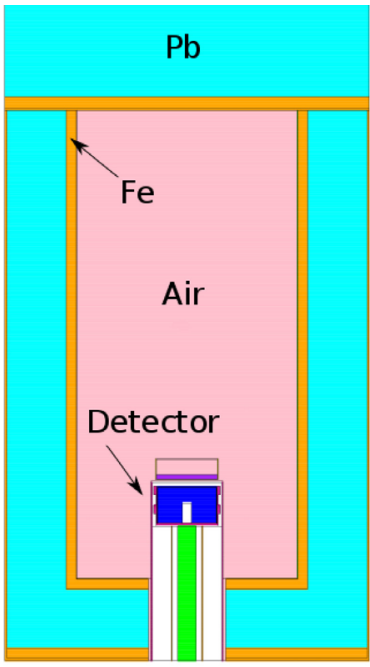

Fig. 1. Structure of the simulated HPGe detector (a) with iron-lead shield (b).

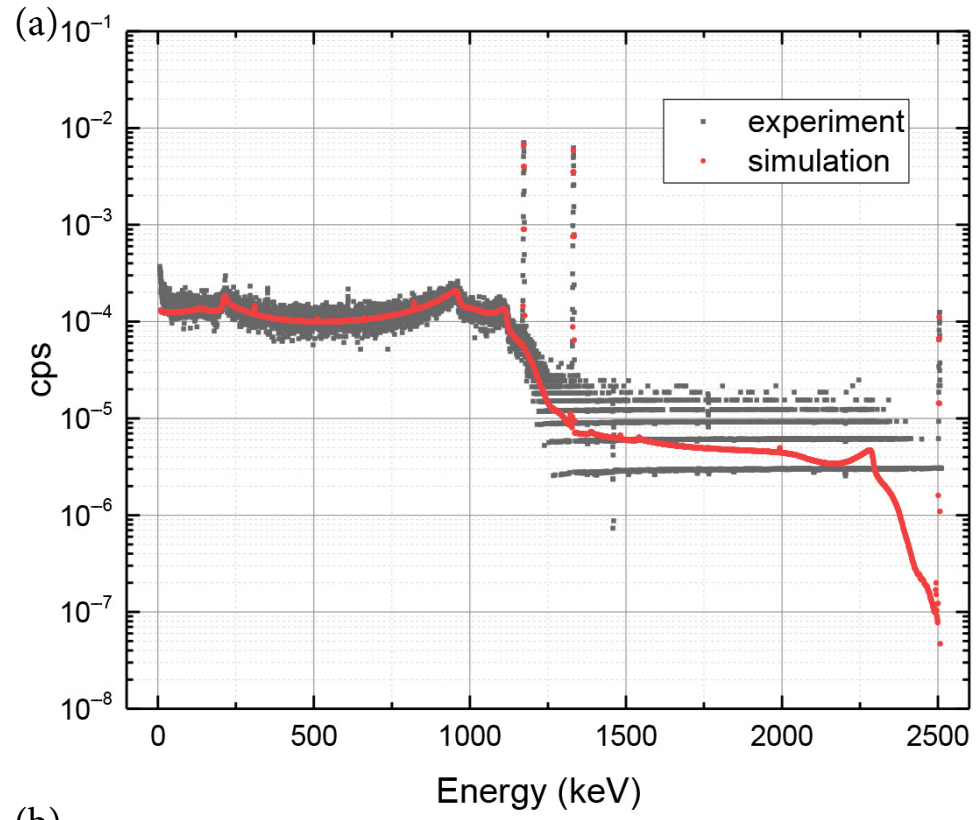

(b)

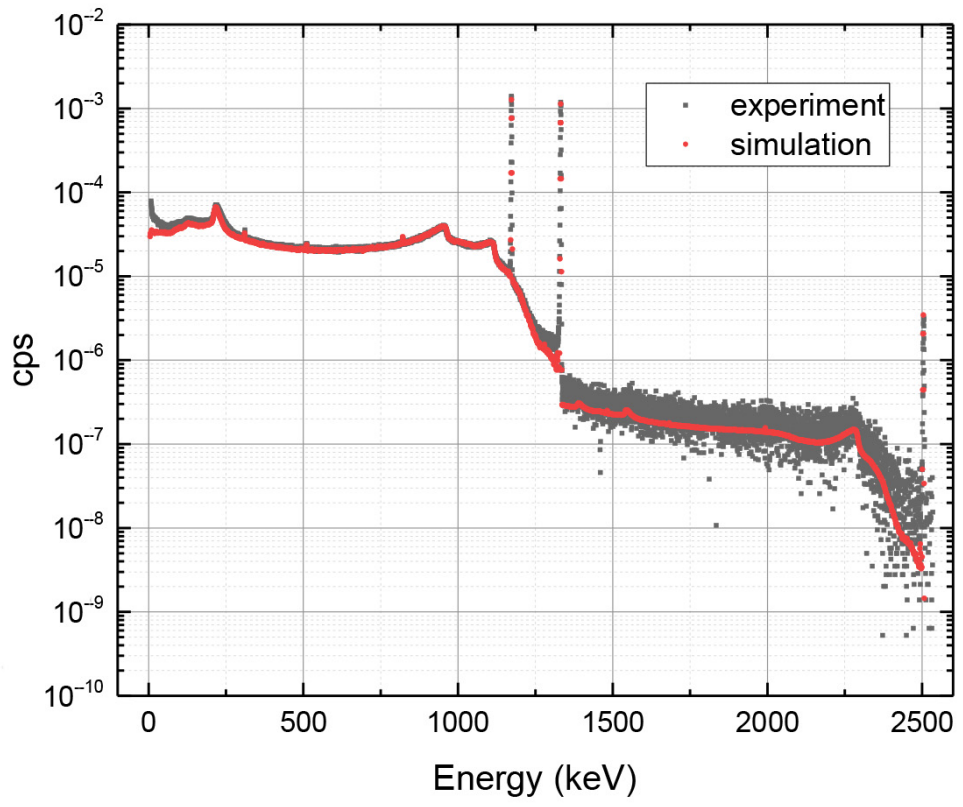

Fig.2.Experimental(withoutbackground) and simulated spectra of the ${ }^{60} \mathrm{Co}$ volume source with different filling heights: (a) $5 \mathrm{~mm}$ (the source is placed on the detector end-cap, acquisition time 1375 s), (b) $22 \mathrm{~mm}$ (the source is elevated at 44 $\mathrm{mm}$ from the detector end-cap, acquisition time $76454 \mathrm{~s})$. Energy bin is $0.9 \mathrm{keV}$. 
Table 1. Information of measurement sources (combined standard uncertainty is $2.4 \%$, reference date 1.1.2020).

\begin{tabular}{ccc}
\hline Source & Activity, $\mathrm{kBq}$ & Filling height, $\mathrm{mm}$ \\
\hline$\# 1$ & 0.667 & 5 \\
\hline$\# 2$ & 1.505 & 10 \\
\hline$\# 3$ & 2.970 & 22 \\
\hline
\end{tabular}

\subsection{Monte Carlo simulations}

The modelling of the high purity germanium (HPGe) detector efficiency was performed by using the Monte Carlo radiation transport code MCNP version 6.2 [14]. One area of applications of the code is widely used for detector design and analysis to investigate the performance data of the detector [15-18]. The geometry setup of Ge crystal and its shielding, used in the simulation, are presented in Figs. 1 $(a, b)$, respectively.

Detector dimensions and other parameters that are provided by the manufacturer are presented in Table 2. Shielding parameters were taken from the self-made experimental setup. The detector efficiency was obtained via the MCNP intrinsic function - pulse height F8 tally. The geometry and materials setup of the HPGe detector and shielding is included in the MCNP input file. To achieve sufficient statistical uncertainties $10^{8}$ particles were used in each run.

Table 2. Detector geometry parameters provided by the manufacturer and adjusted by simulation.

\begin{tabular}{c|c|c}
\hline & $\begin{array}{c}\text { Manufacturer's } \\
\text { provided } \\
\text { value, } \mathrm{cm}\end{array}$ & $\begin{array}{c}\text { Adjusted } \\
\text { value, } \mathrm{cm}\end{array}$ \\
\hline Crystal radius & 3.025 & 2.75 \\
\hline Crystal length & 3.65 & 3.65 \\
\hline Ge dead-layer thickness & 0.05 & 0.05 \\
\hline $\begin{array}{c}\text { Al end-cap distance to } \\
\text { the crystal }\end{array}$ & 0.65 & 0.7
\end{tabular}

While modelling the detector response function for the ${ }^{60} \mathrm{Co}$ source, the coincidence summing must be taken into account. This is because ${ }^{60} \mathrm{Co}$ emits 1.173 and $1.332 \mathrm{MeV}$ gamma quanta in cascade, i.e. in a very short period of time that is comparable with the detector response time. Therefore, the simultaneous detection of separate gammas may oc- cur producing in a spectrum their sum peak. All pulses corresponding to energies above $1.332 \mathrm{MeV}$ are caused by coincidence events not only of the sum peak, but also of the continuum preceding it. However, the intensity of the coincidence peak is low, and not in all cases it was detected in the spectrum. If ${ }^{60} \mathrm{Co}$ gammas were not emitted in cascade, intensities that the detector would register were up to few percent higher compared to the case with the cascades taken into account. The impact of the coincidence summing depends on the sampleto-detector distance.

The coincidence-summing calculations were performed in the following way: first, monoenergetic gammas of ${ }^{60} \mathrm{Co}$ were simulated (i.e. 1.173 and $1.332 \mathrm{MeV}$ ). Data for the pulse height F8 tally in the output file of simulation consist of a range of energy intervals, the so-called bins that are arranged in an increasing order. Each of the energy intervals is given a simulated probability of its detection, as well as the calculation uncertainty. Then, having these results, we apply the formula [19]

$$
\begin{aligned}
& C\left(E_{n}\right)=C\left(E_{n}\right)_{1173}\left[1-\sum_{m=1}^{M} C\left(E_{m}\right)_{1332}\right]+ \\
& C\left(E_{n}\right)_{1332}\left[1-\sum_{m=1}^{M} C\left(E_{m}\right)_{1173}\right]+ \\
& \sum_{m=1}^{n} C\left(E_{m}\right)_{1173} C\left(E_{n-m}\right)_{1332},
\end{aligned}
$$

where $E_{n}$ is the counts in the $n$th interval corresponding to energy $E_{n}, m$ and $n$ are interval numbers, $M$ is the highest interval number, and 1173 and 1332 refer to simulated gammas. The FORTRAN code was written for the calculation of coincidence summing according to this formula and the bash shell script was used for performing routine calculations.

The procedure of geometry adjusting was as follows. As known, the change of the crystal diameter changes the detector efficiency in all energy spectra of the source. Changing the inner radius and the depth of the holes of the crystal, as well as the crystal length affects the efficiency more in the high energy spectrum than the spectrum at low energies, because in this case the absorption of the low-energy quanta does not change so much as the absorption of the high-energy quanta. The dead layer has a shielding effect, therefore the changing of the dead layer thickness affects more the low-energy quanta than the high-energy 
quanta. The thickness of the aluminum end-cap also has a shielding effect, and varying the distance from the aluminum end-cap to the crystal helps in the case when the detector efficiency differs for the same source, but at different source placing heights. A more detailed procedure of geometry adjustment is given in [11].

Coincidences were not registered with container filling levels of $5 \mathrm{~mm}$ and elevation of 22 and $44 \mathrm{~mm}$. The lowest activity when coincidences were registered was $0.055 \mathrm{~Bq}$. The lifetime of excited states in the nucleus is picoseconds; the response time of the detector is microseconds. For ${ }^{60} \mathrm{Co}$, the time between stages is $0.713 \mathrm{ps}$, for the HPGe coaxial detector, it is on the order of $\mu$ s.

\section{Results and discussion}

Two types of detector simulation for this particular experiment were performed. The detector was first simulated by using the geometry provided by the manufacturer (see Table 2). The results are shown in Table 3 . The difference between simulations and measurements is significant and it is as high as $32 \%$. Although the simulation-experiment ratio is quite stable for different filling heights of the sample, see the standard deviation value of all MCNP/experiment data. In this case the simulation results can be related to the experimental data by using the approximate factor 1.3, which is an average value of the ratio of the simu- lation-experiment results. Figure 2 shows an example of the comparison of the measured spectrum and the simulated one. The spectra in Fig. 2, in order to compare them to the experimental results, were modified applying Gaussian broadening. While obtaining the spectra, the simulated energy is broadened by sampling from the Gaussian distribution [20]

$$
f(E)=C \mathrm{e}^{-\left(\left(E-E_{0}\right) / A\right)^{2}},
$$

where $E$ is the broadened energy, $E_{0}$ is the unbroadened energy, $A$ is the Gaussian width, and $C$ is the normalization constant. The Gaussian width equals

$$
A=\frac{\mathrm{FWHM}}{2 \sqrt{\ln 2}},
$$

where FWHM is full width at half maximum and is obtained from the experiment spectra. The value of $1.74 \mathrm{keV}$ was used in our case.

Discrepancies between simulation and experiment might occur because of many reasons: parameters provided by the manufacturer might be not accurate, because they might be measured at room temperature, although in the laboratory detector's working temperature is approximately $-196^{\circ} \mathrm{C}$, because it is cooled down with liquid nitrogen. This might lead to some deformations of the crystal. Other reasons are the detector ageing,

Table 3. The experimental and simulated values of the efficiency of ${ }^{60} \mathrm{Co}$ samples in the case of manufacturer's

\begin{tabular}{|c|c|c|c|c|c|c|c|c|c|c|}
\hline \multirow{2}{*}{ 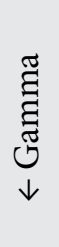 } & & \multicolumn{3}{|c|}{ MCNP } & \multicolumn{3}{|c|}{ Experiment } & \multicolumn{3}{|c|}{$\begin{array}{c}\text { MCNP/ } \\
\text { experiment }\end{array}$} \\
\hline & $\begin{array}{c}\text { filling height } \rightarrow \\
\downarrow \text { elevation } \\
(\mathrm{mm})\end{array}$ & 5 & 10 & 22 & 5 & 10 & 22 & 5 & 10 & 22 \\
\hline \multirow{3}{*}{ 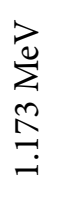 } & 0 & $1.96 \mathrm{E}-2$ & $1.73 \mathrm{E}-2$ & $1.43 \mathrm{E}-2$ & $1.53 \mathrm{E}-2$ & $1.36 \mathrm{E}-2$ & $1.13 \mathrm{E}-2$ & 1.28 & 1.27 & 1.27 \\
\hline & 22 & $8.70 \mathrm{E}-3$ & $7.90 \mathrm{E}-3$ & $6.78 \mathrm{E}-3$ & $6.73 \mathrm{E}-3$ & $6.20 \mathrm{E}-3$ & $5.35 \mathrm{E}-3$ & 1.29 & 1.27 & 1.27 \\
\hline & 44 & $4.69 \mathrm{E}-3$ & $4.33 \mathrm{E}-3$ & $3.81 \mathrm{E}-3$ & $3.63 \mathrm{E}-3$ & $3.35 \mathrm{E}-3$ & $2.99 \mathrm{E}-3$ & 1.29 & 1.29 & 1.28 \\
\hline \multirow{4}{*}{ 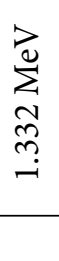 } & 0 & $1.99 \mathrm{E}-2$ & $1.54 \mathrm{E}-2$ & $1.28 \mathrm{E}-2$ & $1.34 \mathrm{E}-2$ & $1.17 \mathrm{E}-2$ & $9.84 \mathrm{E}-3$ & 1.30 & 1.32 & 1.30 \\
\hline & 22 & $8.18 \mathrm{E}-3$ & $7.05 \mathrm{E}-3$ & $6.07 \mathrm{E}-3$ & $5.90 \mathrm{E}-3$ & $5.39 \mathrm{E}-3$ & $4.67 \mathrm{E}-3$ & 1.32 & 1.31 & 1.30 \\
\hline & 44 & $4.31 \mathrm{E}-3$ & $3.87 \mathrm{E}-3$ & $3.41 \mathrm{E}-3$ & $3.17 \mathrm{E}-0$ & $2.92 \mathrm{E}-3$ & $2.61 \mathrm{E}-3$ & 1.32 & 1.32 & 1.31 \\
\hline & & & & & \multicolumn{3}{|c|}{ standard deviation $\rightarrow$} & \multicolumn{3}{|c|}{$1.82 \mathrm{E}-02$} \\
\hline
\end{tabular}
provided detector parameters. 
the dead layer thickness and shape, the shape of working volume, also possible some commercial secrets. Every single detector, having in mind the complexity of the manufacturing process, is unique, therefore fine-tuning of detector parameters is essential in Monte Carlo detector simulation. Also, not the least factor is the experimental setup. Errors may be caused by deformations due to the weight placed upon the detector while taking measurements.

Another type of simulation is the fine-tuning of detector geometry: diameter, length, dead layer thickness, inner radius of the crystal hole, as well as the thickness of aluminium end-cap and the distance to the crystal.

In our case, the ratio of efficiencies of simulation and experiment depends little on the sampleto-crystal distance, therefore, in order to reduce the dependence of the counting efficiency obtained by simulation on the height of the sample placement, the distance of the aluminum end-cap from the crystal should be increased only by $0.5 \mathrm{~mm}$. When the distance changed by $0.5 \mathrm{~mm}$, as well as the crystal diameter changed by $0.2 \mathrm{~mm}$, the simulation error was $1.5 \%$. The main adjustment was made by changing the crystal diameter. The results are shown in Table 2. There was no need to change other parameters of the crystal, since the obtained uncertainties of no more than $3 \%$ are acceptable and meet the criteria of $5-10 \%$ [20].
The simulation results, obtained utilising these parameters, are shown in Table 4. In this case the difference between simulations and measurements is not more than $3 \%$. These results can be used for practical calibration of the detector. Both simulation methods might be used in routine measurements because in such a case the uncertainties of $5-10 \%$ are acceptable [21].

\section{Conclusions}

In this paper, the numerical simulation of gamma-ray interaction with the HPGe detector has been done and compared with the experimental measurements. Analysing the simulation results it was found that the factors that affect the accuracy of simulation are the thickness of the dead layer, the diameter of the crystal, and the height and the thickness of the $\mathrm{Al}$ detector cap. In our case, we had to adjust the crystal diameter and (slightly) the distance from the crystal to the $\mathrm{Al}$ detector cap. The accuracy of both types of our simulation is sufficient. It fulfils criteria of $5-10 \%$ for such type of simulation compared to the experimental data. Thus, it is possible to simulate samples in standard BURK-60 containers of different filling heights.

The second type of simulation, where detector geometry parameters are adjusted, gives, in this case, additional information about the crystal

Table 4. The experimental and simulated values of the efficiency of ${ }^{60} \mathrm{Co}$ samples in the case of MCNP adjusted detector parameters.

\begin{tabular}{|c|c|c|c|c|c|c|c|c|c|c|}
\hline \multirow{2}{*}{ 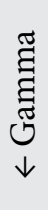 } & \multirow[b]{2}{*}{$\begin{array}{c}\text { filling height } \rightarrow \\
\downarrow \text { elevation } \\
\quad(\mathrm{mm})\end{array}$} & \multicolumn{3}{|c|}{ MCNP } & \multicolumn{3}{|c|}{ Experiment } & \multicolumn{3}{|c|}{ MCNP/experiment } \\
\hline & & 5 & 10 & 22 & 5 & 10 & 22 & 5 & 10 & 22 \\
\hline \multirow{3}{*}{ 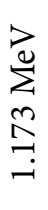 } & 0 & $1.54 \mathrm{E}-2$ & $1.36 \mathrm{E}-2$ & $1.12 \mathrm{E}-2$ & $1.53 \mathrm{E}-2$ & $1.36 \mathrm{E}-2$ & $1.13 \mathrm{E}-2$ & 1.01 & 0.998 & 0.995 \\
\hline & 22 & $6.69 \mathrm{E}-3$ & $6.07 \mathrm{E}-3$ & $5.20 \mathrm{E}-3$ & $6.73 \mathrm{E}-3$ & $6.20 \mathrm{E}-3$ & $5.35 \mathrm{E}-3$ & 0.99 & 0.979 & 0.972 \\
\hline & 44 & $3.58 \mathrm{E}-3$ & $3.30 \mathrm{E}-3$ & $2.91 \mathrm{E}-3$ & $3.63 \mathrm{E}-3$ & $3.35 \mathrm{E}-3$ & $2.99 \mathrm{E}-3$ & 0.986 & 0.985 & 0.973 \\
\hline \multirow{4}{*}{ 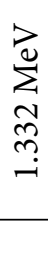 } & 0 & $1.37 \mathrm{E}-2$ & $1.21 \mathrm{E}-2$ & $9.98 \mathrm{E}-3$ & $1.34 \mathrm{E}-2$ & $1.17 \mathrm{E}-2$ & $9.84 \mathrm{E}-3$ & 1.02 & 1.03 & 1.01 \\
\hline & 22 & $5.95 \mathrm{E}-3$ & $5.40 \mathrm{E}-3$ & $4.66 \mathrm{E}-3$ & $5.90 \mathrm{E}-3$ & $5.39 \mathrm{E}-3$ & $4.67 \mathrm{E}-3$ & 1.01 & 1.00 & 0.999 \\
\hline & 44 & $3.18 \mathrm{E}-3$ & $2.94 \mathrm{E}-3$ & $2.59 \mathrm{E}-3$ & $3.17 \mathrm{E}-3$ & $2.92 \mathrm{E}-3$ & $2.61 \mathrm{E}-3$ & 1.00 & 1.01 & 0.993 \\
\hline & & & & & \multicolumn{3}{|c|}{ standard deviation $\rightarrow$} & \multicolumn{3}{|c|}{$1.56 \mathrm{E}-02$} \\
\hline
\end{tabular}


working volume and shape, also the aluminium end-cap distance to the crystal. The analysis allows measuring the radionuclides activity concentration of the samples placed in the same geometry containers, but with different filling heights, by using only standard shape calibration sources.

\section{References}

[1] T. Vichaidid, T.Soodprasert, and T. Verapaspong, Calibration of HPGe gamma-ray planar detector system for radioactivity standards, Kasetsart J. (Nat. Sci.) 41, 198-202 (2007), https://li01.tcithaijo.org/index.php/anres/article/view/244368

[2] M.H. Wiggs and C. Schmitt, Measurement of Germanium Detector Efficiency, Notre Dame Physics REU (University of Notre Dame 2009), https://www.semanticscholar.org/paper/Measurement-of-Germanium-DetectorEfficiency-Wiggs-Schmitt/5dea08f8173c1915f9e e03921b607e200de56bd3

[3] A. Gudelis, V. Remeikis, A. Plukis, and D. Lukauskas, Efficiency calibration of HPGe detectors for measuring environmental samples, Environ. Chem. Phys. 22(3-4), 117-125 (2000).

[4] F. Bronson, Validation of the accuracy of the LabSOCS software for mathematical efficiency calibration of Ge detectors for typical laboratory samples, J. Radioanal. Nucl. Chem. 255(1), 137-141 (2003), https://doi. org/10.1023/A:1022248318741

[5] S. Harb, K. Salahel Din, and A. Abbady, in: Proceedings of the 3rd Environmental Physics Conference (Aswan, Egypt, 2008) pp. 207-218, https://inis.iaea.org/search/search.aspx?orig_ $\mathrm{q}=\mathrm{RN}: 41046595$

[6] M.E. Medhat and V.P. Singh, Geant4 Monte Carlo code application in photon interaction parameter of composite materials and comparison with XCOM and experimental data, Indian J. Pure Appl. Phys. 54(02), 137-143 (2016), https://nopr. niscair.res.in/handle/123456789/33798

[7] M.T. Haj-Heidari, M.J. Safari, H. Afarideh, and H. Rouhi, Method for developing HPGe detector model in Monte Carlo simulation codes, Radiat. Meas. 88, 1-6 (2016), https://doi.org/10.1016/j. radmeas.2016.02.035
[8] M.E. Medhat and Y. Wang, Estimation of background spectrum in a shielded HPGe detector using Monte Carlo simulations, Appl. Radiat. Isotopes 84, 13-18 (2014), https://doi. org/10.1016/j.apradiso.2013.10.017

[9] F. Courtine, S. Sanzelle, T. Pilleyre, and D. Miallier, Calibration of a germanium well-detector using ${ }^{60} \mathrm{Co}$ : The effects of the angular correlation of the two gamma rays emitted in cascade, quantified with Monte Carlo simulations, Radiat. Meas. 61, 78-82 (2014), https://doi.org/10.1016/j.radmeas.2013.11.007

[10]C. Agarwal, S. Chaudhury, A. Goswami, and M. Gathibandhe, True coincidence-summing corrections in point and extended sources, J. Radioanal. Nucl. Chem. 289, 773-780 (2011), https://doi.org/10.1007/s10967-011-1126-7

[11]C. Agarwal, S. Chaudhury, A. Goswami, and M. Gathibandhe, Full energy peak efficiency calibration of HPGe detector for point and extended sources using Monte Carlo code, J. Radioanal. Nucl. Chem. 287, 701-708 (2011), https://doi. org/10.1007/s10967-010-0820-1

[12] R.G. Helmer, J.C. Hardy, V.E. Iacob, M. SanchezVega, R.G. Neilson, and J. Nelson, The use of Monte Carlo calculations in the determination of a Ge detector efficiency curve, Nucl. Instrum. Meth. A 511(3), 360-381 (2003), https://doi. org/10.1016/S0168-9002(03)01942-9

[13]E. Andreotti, M. Hult, G. Marissens, G. Lutter, A. Garfagnini, S. Hemmerb, and K. von Sturm, Determination of dead-layervariation in HPGe detectors, Appl. Radiat. Isotopes 87, 331-335 (2014), https://doi.org/10.1016/j.apradiso.2013.11.046

[14]C.J. Werner, J.S. Bull, C.J. Solomon, F.B. Brown, G.W. McKinney, M.E. Rising, D.A. Dixon, R.L. Martz, H.G. Hughes, L.J. Cox, et al., MCNP Version 6.2 Release Notes (Los Alamos National Lab. (LANL), Los Alamos, NM, United States, 2018), https://www.osti.gov/biblio/1419730-mcnpversion-release-notes

[15]P. Andersson, V. Rathore, L. Senis, A. Anastasiadis, E. Andersson Sundén, H. Atak, S. Holcombe, A. Håkansson, P. Jansson, and J. Nyberg, Simulation of the response of a segmented high-purity germanium detector for gamma emission tomography 
of nuclear fuel, SN Appl. Sci. 2, 271 (2020), https://doi.org/10.1007/s42452-020-2053-4

[16]C. Thiam, M. Anagnostakis, R. Galea, D. Gurau,

S. Hurtado, K. Karfopoulos, J. Liang, H. Liu, A. Luca, I. Mitsios, et al., A benchmark for Monte Carlo simulation in gamma-ray spectrometry, Appl. Radiat. Isotopes 154, 108850 (2019), https://doi.org/10.1016/j.apradiso.2019.108850

[17]T. Marchais, B. Pérot, C. Carasco, P.-G. Allinei, P. Chaussonnet, J.-L. Ma, and H. Toubon, Detailed MCNP simulations of gamma-ray spectroscopy measurements with calibration blocks for uranium mining applications, IEEE Trans. Nucl. Sci. 65(9), 2533-2538 (2018), https://ieeexplore.ieee. org/document/8268552

[18]C.J. Tichacek, M.M. Budzevich, T.J. Wadas, D.L. Morse, and E.G. Moros, A Monte Carlo method for determining the response relationship between two commonly used detectors to indirectly measure alpha particle radiation acti- vity, Molecules 24(18): 3397 (2019), https://www. ncbi.nlm.nih.gov/pmc/articles/PMC6767018

[19]Z. Wang, B. Kahn, and J.D. Valentine, Efficiency calculation and coincidence-summing correction for germanium detectors by Monte Carlo simulation, IEEE Trans. Nucl. Sci. 49(4), 19251931 (2002), https://ieeexplore.ieee.org/document/1043597

[20]E. Eftekhari Zadeh, S.A.H. Feghhi, E. Bayat, and G.H. Roshani, Gaussian energy broadening function of an HPGe detector in the range of $40 \mathrm{keV}$ to $1.46 \mathrm{MeV}$, J. Exp. Phys. 2014, 1-4 (2014), https://doi.org/10.1155/2014/623683

[21]M.C. Lépy, T. Altzitzoglou, D. Arnold, F. Bronson, R. Capote Noy, M. Décombaz, F. De Corte, R. Edelmaier, E. Herrera Peraza, S. Klemola, et al., Intercomparison of efficiency transfer software for gamma-ray spectrometry, Appl. Radiat. Isotopes 55(4), 493-503 (2001), https://doi. org/10.1016/S0969-8043(01)00101-4

\title{
GRYNO GERMANIO DETEKTORIAUS EFEKTYVUMO KALIBRAVIMAS MONTE KARLO METODU SU SUTAPČIŲ SUMAVIMO PATAISOMIS: TŪRINIO ŠALTINIO ATVEJIS
}

\author{
M. Konstantinova, D. Germanas, A. Gudelis, A. Plukis \\ Valstybinis moksliniu tyrimu institutas Fiziniu ir technologijos mokslu centras, Vilnius, Lietuva
}

\begin{abstract}
Santrauka
Gama spektrometrija naudojant germanio detektorius taikoma mažo aktyvumo skirtingos geometrijos aplinkos mèginiams (dirvožemio méginiams, oro filtrams su aerozoliais, pieno milteliams ir pan.) tirti. Tokie matavimai reikalauja atskiro detektorių kalibravimo. Eksperimentams buvo naudojamas GC2520 serijos gryno germanio (HPGe) gama spektrometras. Buvo atsižvelgta ị gamintojo pateiktus gryno germanio kristalo matmenis. Efektyvumui kalibruoti buvo naudojami trijų skirtingų užpildymo laipsnių cilindriniai indai su ${ }^{60} \mathrm{Co}$ vandeniniu tirpalu. Gama spinduliuotès sutapčiu sumavimas buvo modeliuotas naudojant MCNP6. Tikru sutapčių sumavimu laikomas ịvykis, kai du ar daugiau gama kvantų, kurie kaskadu sklinda iš sužadinto branduolio, aptinkami per detektoriaus skyrimo trukmę.
\end{abstract}

Dažnai pastebima neatitiktis tarp modeliuotų ir eksperimentiškai nustatytų efektyvumo verčių. Palyginti eksperimentiškai gauti ir sumodeliuoti spektrai. Geras eksperimentinių ir sumodeliuotų rezultatų nuoseklumas leidžia tirti tūrinius šaltinius. Modeliuojant nustatyta, kad veiksniai, darantys itaką modeliavimo tikslumui, yra neveikos sluoksnio storis, kristalu matmenys ir detektoriaus kriostato apvalkalo iš aliuminio storis. Analizè leidžia išmatuoti radionuklidų savitajj aktyvumą skirtingo aukščio mèginių, idètų i BURK-60 indus, turint tik standartinius kalibravimo šaltinius. Mūsų modeliavimo tikslumas atitinka 5-10 \% kriterijus, taikomus tokio tipo modeliavimui, ir šie rezultatai gali būti naudojami eksperimentuose imituojant ịvairių užpildų ir aukščių standartinių BURK-60 konteinerių šaltinius. 